(Valle, 1970), decreased wall hugging would appear to be the expression of decreased fearfulness. Second, the younger animals engaged in more grooming behavior than did the older rats. Other studies (e.g., Hahn, Morrison, Simmel, \& Harris, 1970) have found increased grooming to be an expression of decreased emotionality. Third, the younger animals showed a decrease in defecation over tests, while the oldest animals showed a relatively constant level of defecation. Amount of defecation has frequently been cited as an index of emotionality (Broadhurst, 1958; Ivinkis, 1966; Pare, 1964).

'I'his is not to say, of course, that in addition to being less fearful, the younger animals might not also have been more curious than the older rats. Such an assumption, however, does not appear necessary to account for the data of the present experiment.

Figure 6 illustrates one way in which the effects of repeated tests on the approach and withdrawal tendencies of young and old rats might be conceptualized. As can be seen, it has been assumed that the strengths of the approach tendencies for young and old rats are equal. It has also been assumed that the approach tendency has a faster rate of decay (undergoes relatively more habituation on the early tests) than the withdrawal tendency. Additionally, it has been assumed that the withdrawal tendency of the younger rats is initially lower and habituates to a lower asymptote than that of the older rats. Finally, it is proposed that amount of locomotion is determined by the difference in strength between the tendency to approach and the tendency to withdraw. From these assumptions it is possible to explain: (1) the overall greater amount of locomotion shown by the younger animals; (2) the initial decrement and subsequent recovery in locomotion shown by the younger animals; and (3) the initial decrement and persistent depression in locomotion shown by the older animals.

Finally, it is possible that the funetion relating open-field activity to age is influenced by strain variables. Thus, for a given strain of rats, the relationship between age and activity may be, within wide limits, either monotonically negative or positive, and it is only by combining results from different strains that a curvilinear relationship is obtained. For example, Broadhurst (1958), who reported an increase in locomotion from 50 to 100 days, used Ss selectively bred for high emotionality. The present study, in contrast, found a decrease in activity between 50 to 90 and 90 to 150 days, using randomly bred Sprague-Dawley rats. Until the effects of strain on age-related changes in open-field activity are more fully investigated, the generality of conclusions must necessarily be limited.

\section{REFERENCES}

BROADHURST, P. L. Determinants of emotionality in the rat: II. Antecedent factors. British Journal of Psychology. $1958,49,12-20$

DOTY, B. A., \& DOTY, L. A. Effects of $h$ andling at various ages on later open-field behaviour. Canadian Journal of Psy chology, 1967, 21, 463-470.

FURCHTGOTT, E. WECHKIN, S, \& DEES, J. W. Open-field exploration as a function of age. Joumal of Comparative \& Physiological Psychology, 1961,54, 386-388.

HAHN, M. E., MORRISON, B. J., SIMMEL,
E. C., \& HARRIS, C. J. Atypical effects of electroshock on emotionality in rats. Psychonomic Science, 1970, 21, 159-160.

IVINSKIS, A. A note on the open-field test of emotionality. Australian Journal of Psychology, 1966, 18, 276-280.

MONTGOMERY, $\mathrm{K}$. C. The relation between fear induced by novel stimulation and exploratory behavior. Journal of Comparative \& Physiological Psychology, 1955, 48, 254-260.

PARE, W. P. Relationship of various behaviors in the open-field test of emotionality. Psychological Reports, $1964,14,19-22$.

VALLE, F. P. Effects of strain, sex and illumination on open-field behavior of rats. American Journal of Psychology, $1970,83,103-111$.

WERBOFF, J., \& HAVLENA, J. Effects of aging on open-field behavior. Psychological Reports, 1962, 10, 395-398.

\title{
The role of site familiarity in aggression toward strangers in the Mongolian gerbil
}

\author{
STANLEY WECHKIN and RUTH C. CRAMER \\ State University of New York, College at Brockport, Brockport, N.Y. 14420
}

Groups consisting of three gerbils each were tested for aggression toward strange conspecifics in a familiar and an unfamiliar situation. Aggression was significantly higher in the familiar situation, indicating that territorial defense is characteristic of this species. It is suggested that exploration of the unfamiliar environment precluded aggression toward strangers and that the discrimination of strangers is based on olfaction.

It has been noted that, while established groups of gerbils will live peaceably even within the crowded confines of laboratory quarters, the introduction of a strange conspecific frequently results in the elicitation of aggression, culminating in the death of the newcomer. 1 While such behavior may be adaptive in terms of maintaining group integrity, limiting population, etc. (Wynne-Edwards, 1962), the nature of the eliciting stimulus is not clear. It may be hypothesized that it is the stranger in the context of the familiar site that results in aggression, that this aggression is actually a territorial defense. Such an explanation would be consonant with the findings of Thiessen (1968), which indicated that gerbils are territorial. Alternately, it may be argued that it is the newcomer's strangeness vis à vis the other animals of the group, his character as a contextually novel social stimulus, that elicits the attack. If the latter explanation is the correct one, then strangers would be attacked by group members, regardless of whether or not the intrusion occurred in a previously occupied area. On the other hand, if the basis of this aggression is territorial defense, then more aggression would occur in a familiar site than in an unfamiliar one. Accordingly, in the present experiment, the familiarity of the site was varied and an attempt was made to determine the relationship of this to the amount of hostility to strangers. In addition, the effect of repeated introductions of strangers was assessed.

\section{METHOD}

The Ss were 48 adult male gerbils obtained from Tumblebrook Farm, Brant Lake, N.Y. Of these, 36 were assigned randomly, 3 to a cage, to 12 $18 \times 9 \times 6$ in. stainless steel sheet and mesh cages. These animals were housed together for a period of 5 weeks prior to the onset of testing and constituted the established groups. The remaining 12 Ss were designated as strangers and were similarly housed.

The 12 established groups were assigned randomly to one of two 
Table 1

Mean Incidence of Social Behaviors by Group Members and Strangers Toward Each Other as a Function of Site Familiarity and Time

\begin{tabular}{|c|c|c|c|c|c|c|}
\hline & \multicolumn{3}{|c|}{ Immediate } & \multicolumn{3}{|c|}{5 Hours } \\
\hline & Familiar & Unfamiliar & $t$ & Familiar & Unfamiliar & $\mathbf{t}$ \\
\hline & \multicolumn{6}{|c|}{ Pursue } \\
\hline Group & 6.47 & .44 & $4.67 t$ & .02 & .25 & 2.04 \\
\hline \multirow[t]{2}{*}{ Stranger } & .03 & .00 & $<1.00$ & .00 & .02 & $<1.00$ \\
\hline & \multicolumn{6}{|c|}{ Flee } \\
\hline Group & .02 & .00 & $<1.00$ & .00 & .02 & $<1.00$ \\
\hline \multirow[t]{2}{*}{ Stranger } & 7.03 & .61 & $4.93+$ & .02 & .19 & $<1.00$ \\
\hline & \multicolumn{6}{|c|}{ Squint } \\
\hline \multirow[t]{2}{*}{$\begin{array}{l}\text { Group } \\
\text { Stranger }\end{array}$} & $\begin{array}{l}3.67 \\
1.70\end{array}$ & $\begin{array}{l}.44 \\
.17\end{array}$ & $\begin{array}{l}2.99^{*} \\
3.82 \dagger\end{array}$ & $\begin{array}{l}3.17 \\
2.83\end{array}$ & $\begin{array}{l}1.31 \\
1.00\end{array}$ & $\begin{array}{r}1.08 \\
<1.00\end{array}$ \\
\hline & \multicolumn{6}{|c|}{ Rear } \\
\hline \multirow[t]{2}{*}{$\begin{array}{l}\text { Group } \\
\text { Stranger }\end{array}$} & $\begin{array}{l}1.56 \\
1.28\end{array}$ & $\begin{array}{l}.25 \\
.11\end{array}$ & $\begin{array}{l}2.19 \\
2.09\end{array}$ & $\begin{array}{l}1.36 \\
1.56\end{array}$ & $\begin{array}{l}.28 \\
.28\end{array}$ & $\begin{array}{l}1.64 \\
1.58\end{array}$ \\
\hline & \multicolumn{6}{|c|}{ Sniff } \\
\hline Group & 13.06 & 10.09 & $3.38+$ & 2.03 & 2.28 & $<1,00$ \\
\hline \multirow[t]{2}{*}{ Stranger } & 4.06 & 5.92 & 2.21 & 1.39 & 2.11 & 1.65 \\
\hline & \multicolumn{6}{|c|}{ Lick } \\
\hline Group & 4.20 & .35 & $5.04 t$ & .56 & .22 & 1.60 \\
\hline Stranger & .19 & .00 & 2.17 & .06 & .03 & $<1.00$ \\
\hline
\end{tabular}

$*_{p}<.05$ (two-tailed, $\left.d f=10\right),+p<.01$ (two-tailed, $d f=10$ )

conditions. In the familiar site condition, the cage containing the group was moved, with its occupants, to an observation area $24 \mathrm{~h}$ prior to the introduction of the stranger and the beginning of testing. In the unfamiliar site condition, testing began with the members of the group and the stranger being simultaneously placed in a newly cleaned cage similar to the one in which they had been housed.

Testing consisted of recording the presence or absence of each of 11 behaviors of possible social significance selected on the basis of their occurrence during competitive encounters between gerbils in the course of a prior experiment (Wechkin \& Reid, 1970). These responses were: pursue, flee, jump, squint, rear up, sniff, lick, chew, nip, and crawl underneath, all with respect to another animal, plus hindleg thump. Scores in each category were the number of 30 -sec intervals in which the response occurred. The behavior of the stranger to the group, that of the members of the group to the stranger, and that of the group members to each other were separately noted. Two test periods were used: the first was between 10:00 and 11:00 a.m. and began immediately upon the introduction of the stranger; the second test period was $5 \mathrm{~h}$ later. The stranger remained with the group for $24 \mathrm{~h}$, following which all animals were returned to their home rack. Each group was tested once a week for 6 weeks, each test employing a different stranger. Four groups, two from each condition, were tested on each test day, and the order of testing was counterbalanced across conditions. The Ss could hear, but not see, animals in nearby cages during testing.

\section{RESULTS}

Of the 11 response categories, five (jump, chew, nip, crawl underneath, and hindleg thump) occurred very infrequently and were not considered further. The data for the other responses on the part of both strangers and group members appear in Table 1 . The pursue, flee, squint, and rear responses may be regarded as components of agonistic behavior and sniff and lick, as exploration. As may be seen, there was a higher frequency of almost all of these behaviors under the familiar site condition, and the difference between site conditions was greatest just after the stranger was introduced. Though both stranger and group members exhibited considerable agonistic behavior, the direction of aggression is clear from the scores in the pursue and flee categories-the group members were almost always the pursuers and almost never fled, and the reverse was true for the strangers.

Of the five cases where the stranger was killed, four occurred in the familiar site condition; however, these four deaths were caused by the members of a single group.

No systematic change in any response category was evident over the 6 test weeks for either the group members or the strangers in either condition. This would appear to indicate that the group members became neither more nor less tolerant towards strangers with successive exposures, and strangers, each of whom was used at least once a week, became neither more nor less adept at dealing with the aggression of the group members.

\section{DISCUSSION}

The data indicate that gerbil aggression to strange conspecifics is maximized in the context of a familiar area. Part of the explanation for the relatively low-level aggression in the unfamiliar situation may lie in the high level of exploration towards inanimate parts of the environment elicited therein. Though no record was made of these responses, it was evident that the animals placed in the new cage spent much of the first 10 -min test period exploring it, and, of course, these responses were incompatible with aggression. Presumably, by the time the strange environment had become familiar, so had the strange animal.

The high incidence of social sniffing observed immediately after the introduction of the stranger in both the familiar and unfamiliar situations on the part of both group members and strangers corroborates and extends the importance that Thiessen and his coworkers (Thiessen, 1968; Nyby, Thiessen, \& Wallace, 1970) attribute to olfactory stimuli in the maintenance of territory in gerbils. These investigators have found that territoriality in gerbils is accomplished by the presence of smelly sebum secreted by territory owner upon inanimate objects; the present study indicates that the odor of the animals themselves is also important. The significance of such body odors in determining aggression has been demonstrated for mice by Ropartz (1968); that these odors probably also control gerbil aggression is borne out by the finding (unpublished) that anosmic gerbils do not attack a stranger even in their own home cage.

\section{REFERENCES}

NYBY, J., THIESSEN, D. D. \& WALLACE $P$. Social inhibition of territorial marking in the Mongolian gerbil (Meriones unguiculatus). Psychonomic Science, $1970,21,310-312$.

ROPARTZ, P. The relation between olfactory stimulation and aggressive behavior in mice. Animal Behaviour, $1968,16,97 \cdot 100$.

THIESSEN, D. D. The roots of territorial marking in the Mongolian gerbil: A problem of species-common topography. Behavior Research Methoos \& Instrumentation, 1968, 1, 70-76.

WECHKIN, S., \& REID, R. L. Social competition in the Mongolian gerbil. (Meriones unguiculatus). Psychonomic Science, 1970, 19, 285-286.

WYNNE-EDWARDS, V. C. Animal dispersion in relation to social behavior. New York: Hafner, 1962.

$$
\text { NOTE }
$$

1. Naumann, D. J. Statement of preliminary investigation and observation of the Mongolian gerbil (Meriones unguiculatus). Unpublished manuscript. 1963. 